\title{
Influence of plant extracts, storage containers and storage duration on the physiological quality of watermelon (Citrullus lanatus (Thunb.) Mansf.) seeds stored under ambient conditions
}

\author{
Tolulope Olaitan KEHINDE ${ }^{1,2}$, Olatunde Azeez BHADMUS ${ }^{1}$, Joseph OLUFELO ${ }^{1}$
}

Received January 16, 2020; accepted October 05, 2020.

Delo je prispelo 16. januarja 2020, sprejeto 05. oktobra 2020.

Influence of plant extracts, storage containers and storage duration on the physiological quality of watermelon (Citrullus lanatus (Thunb.) Mansf.) seeds stored under ambient conditions

Abstract: Watermelon seed being an oily seed is prone to rapid deterioration of its quality, hence maintaining quality during storage is germane. The study therefore investigated the effect of crude plant powder, storage containers and storage duration on the seed quality of two varieties of watermelon seeds. Seed lots each of $100 \mathrm{~g}$ of each variety were treated with $10 \mathrm{~g}$ of four crude plant powders of clove basil leaf, red chilli pepper fruit, garlic, neem leaf and a synthetic fungicide. All samples were stored in three storage containers (envelope, tin and glass bottle). Treated seeds were stored under ambient conditions for 180 days. Germination and seedling vigour were determined at 180 day time course after storage. Data were subjected to mean separation using Duncan's Multiple Range Test. Significant differences were observed in the quality traits examined in water melon due to differences in variety, seed treatment, storage container and storage period. 'Kaolak' was the best in storage in terms of seedling vigour and viability. Glass bottle was identified as the best storage container in maintaining seed quality of water melon throughout the storage period. The use of organic materials especially neem and clove basil leaf powder proved much better for maintaining germinability and seedling vigour and extension of seed longevity than inorganic material.

Key words: seed longevity; seed treatment; storage medium; probit modelling; seed storage life
Vpliv rastlinskih pripravkov, načinov in trajanja shranjevanja na fiziološke lastnosti semen lubenice (Citrullus lanatus (Thunb.) Mansf.) shranjenih v ambientalnih razmerah

Izvleček: Semena lubenice vsebujejo veliko olja in so zato podvržena hitremu propadu, zaradi česar je njihovo shranjevanje oteženo. V raziskavi so bili preučevani učinki zmletih izbranih rastlin, načina in trajanja shrambe na kakovost semen dveh sort lubenice. Vzorci semen, vsake od obeh sort lubenice po $100 \mathrm{~g}$, ki so bili tretirani s po $10 \mathrm{~g}$ grobega prahu zmletih listov afriške bazilike, plodov rdečega čilija, strokov česna, listov azadirahta in sintetičnega fungicida so bili nato shranjeni v treh vrstah shranjevalnikov in sicer v papirnatih vrečkah, v kositrnih posodah in steklenicah. Tretirana semena so bila shranjena 180 dni v ambientalnih razmerah. Podatki meritev so bili obdelani z Duncanovim multiplim testom. Ugotovljene so bile značilne razlike v kakovosti semen lubenice glede na sorto, obravnavanje semen, način in trajanje shrambe. Sorta Kaolak je bila po shranjevanju najboljša glede na vitalnost in vigor pridobljenih sejank. Za vzdrževanje kakovosti semen so bile v celotnem obdobju shrambe najboljše steklenice. Uporaba rastlinskih pripravkov, še posebej prah iz listov azadirahta in afriške bazilike, se je za shranjevanje in vzdrževanje kalivosti semen lubenice kot za vigor sejank izkazala boljše kot sintetični fungicid.

Ključne besede: dolgoživost semen; tretiranje semen; način shranjevanja; probit model; dolgoživost shranjenih semen

1 Federal University of Agriculture, Department of Plant Breeding and Seed Technology, Abeokuta, Ogun State, Nigeria

2 Corresponding author, e-mail: kehindeto@funaab.edu.ng 


\section{INTRODUCTION}

Water melon belongs to the genus Citrullus and family Cucurbitaceae (Huxley, 1992). The Cucurbitaceae is a family of medium sized plants, primarily found in the warmer regions of the world. It is recognizable by its pinnatifid leaves and prolific fruition, up to 100 melons on a single vine. The water melon fruit, loosely considered a type of melon, possesses a smooth exterior rind (green and yellow) and a juicy, sweet, usually red, yellow or orange interior flesh (Jeffrey, 2005). Moreover, they are used as a domestic remedy for urinary tract infection, hepatic congestion, catarrh, worm remedy, abnormal blood pressure (Deible and Swanson, 2001; Amadi et al., 2003). Watermelon contains about $6 \%$ sugar and $92 \%$ water by mass. As with many other fruits, it is a source of vitamin C.

Seeds of watermelon are considered to have a longlife span in storage as to its quality (Priestley, 1986). In subtropical regions where watermelon seeds are intensively produced and where high relative humidity (> $70 \%)$ is often accompanied with high temperature (30$35^{\circ} \mathrm{C}$ ), the quality or vigour of the seed can decline drastically within 12-18 months (Demir et al., 2011).

Seed longevity is greatly influenced by the relative humidity and storage temperature. The indiscriminate use of chemicals and their residual toxicity adversely affects the non-target animals and human beings besides affecting the seed quality. Many of the synthetic chemicals are effective but they are not readily degradable physically or biologically and yield more toxic residues. However, the use of chemicals is still in use. Hence, a safe and feasible approach is the treatment of seeds with botanicals which are safe, economical, eco-friendly and non-harmful to seed, animal and human beings (Mahesh and Hunje, 2008).

Watermelon seed being an oily seed is prone to rapid deterioration of its quality and since seed treatment with botanicals have been found to be more suitable and safe in maintaining viability of seeds (Adebisi, 2012), hence this study therefore will investigate the effects of crude plant powders, storage containers, storage duration on the maintenance of the quality of watermelon seeds.

\section{MATERIALS AND METHOD}

\subsection{SEED MATERIALS}

Two varieties of watermelon seeds ('Kaolak' and 'Sugar Baby') were sourced from the Department of Plant Breeding and Seed Technology, Federal University of Agriculture, Abeokuta, Ogun State, Nigeria. Seeds were scooped out from freshly harvested mature fruits and air-dried under ambient temperature for 4 weeks. Seed moisture content was thereafter determined using the oven drying method (ISTA, 1995).

\subsection{EXPERIMENTAL DESIGN}

The experiment was factorial laid out in completely randomized design with three replications. There were four factors to be considered; variety, seed treatment, storage containers and storage time.

\subsection{METHOD OF SEED TREATMENT}

The dried seed lots were treated with crude plant powdered treatments following the methods of Adebisi et al. (2013). Seeds were dry-dressed with four organic material which include finely powdered leaves of clove basil (Ocimum gratissimum L.) leaf (10 g $100 \mathrm{~g}$ of seed $\left.^{-1}\right)$, red chilli (Capsicum frutescens $\mathrm{L}$.) fruit $(10 \mathrm{~g} / 100 \mathrm{~g}$ of seed $\left.^{-1}\right)$, garlic (Allium sativum L.) fruit $\left(10 \mathrm{~g} 100 \mathrm{~g} \mathrm{of} \mathrm{seed}^{*}\right.$

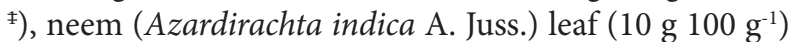
of seed and one inorganic material (Apron plus) while one with no treatment served as the control.

Seeds were dressed with recommended doses in sealed plastic containers at room temperature. After treatment, the storage containers were shaken twice daily up to seven days. Thereafter, the seed were stored in three different moisture pervasive materials (galvanized iron tin, glass bottle, and envelope).

\subsection{SEED STORAGE}

The containers with the treated seeds were kept in seed store under ambient conditions (temp $30{ }^{\circ} \mathrm{C}, \mathrm{RH}$ $75 \%$ ) for 180 days to evaluate the treatment effects on the seed viability and seedling vigour traits.

\subsection{QUALITY ASSESSMENT}

Viability Test: Seed samples were taken from each treatment at $0,30,60,120,150$ and 180 days of storage and was tested for the following seed quality traits. Viability test was carried out in the laboratory. Fifty seeds in three replications were placed inside petri dishes in an incubator and were maintained at $20 \mathrm{ml}$ of distilled water and germination count was taken at 7 days (ISTA, 1995). Seed viability $=$ germination count at 7 days X 100 number of seeds sown 
Seedling Vigour Index: Seedling vigour index (SVI) was calculated by multiplying percentage (\%) viability by the average of seedling length on the 7th day of germination (ISTA, 1995) and divided by 100.

$$
\text { SVI }=\frac{\text { seed viability }(\%) \text { at } 7 \text { days } x \text { seedling length }(\mathrm{cm})}{100}
$$

Seedling Length: Shoot length of 10 randomly selected seedlings were measured using a ruler in centimetre $(\mathrm{cm})$.

\subsection{DATA ANALYSIS}

All data collected were subjected to analysis of variance using Statistical Analysis Software (SAS ${ }^{\mathrm{TM}}, 2002$ ). Significant means were separated using Duncan's Multiple Range Test at $5 \%$ probability level (Duncan, 1955).

The seed viability data were subjected to probit analysis using the PROC statements of SAS in order to predict the storage life of the seeds. Seed longevity parameters were values of $K i$ (an estimate of the probit value of initial seed viability at the time of storage), slope $(1 / \sigma)$, an estimate of rate of seed physiological deterioration, sigma $(\sigma)$, the standard deviation of seed survival curve and an estimate of time taken to lose 1 probit seed viability, and $\mathrm{P}_{50}$, a measure of time taken for a seed lot to lose $50 \%$ viability and estimate of absolute seed longevity (Ellis and Roberts, 1980).

\section{RESULTS}

Table 1 presents the effect of plant extract on seed viability of two water melon varieties stored for 180 days under natural ageing condition. From the result, seeds of 'Kaolak' treated with neem leaf powder had the highest viability value though statistically similar to values obtained in some other treatments at 0 days of storage. At 30 days of storage, 'Kaolak' seeds treated with chilli pepper powder gave the highest viability value $(94.44 \%)$ though statistically similar to those obtained in some other treatments. Treated seeds of 'sugar baby' had comparable values among the treatments. A progressive decline was observed among all the seeds as storage duration increases with 'Kaolak' seeds treated with neem powder still having the highest value among other treatments.

The effect of plant extract on seedling vigour of two water melon varieties is shown in Table 2. Seeds of 'Kaolak' irrespective of the treatments had seedling vigour above sugar baby at 0 day of storage. At 30 days of storage, seeds of 'Kaolak' treated with basil leaf powder gave the highest seedling vigour values though statistically similar to values obtained in some other treatments. It was observed that 'Kaolak' seed treated with neem powder maintained the highest value throughout the storage duration.

Table 3 shows the effect of container and storage time on seed viability of two water melon varieties. Seeds of 'Kaolak' stored in envelope had the highest (98.89\%) statistically similar viability value with other containers

Table 1: Effect of seed treatment on viability (\%) of seeds of watermelon stored under ambient conditions at different storage duration

\begin{tabular}{llllllll}
\hline & & \multicolumn{5}{c}{ Storage Duration (days) } \\
\cline { 3 - 7 } Variety & Treatment & 0 & 30 & 60 & 120 & 150 & 180 \\
\hline Kaolak & Neem & $100 \mathrm{a}$ & $93.33 \mathrm{ab}$ & $88.89 \mathrm{a}$ & $88.89 \mathrm{a}$ & $73.33 \mathrm{a}$ & $56.67 \mathrm{a}$ \\
& Clove basil & $97.78 \mathrm{a}$ & $87.78 \mathrm{ab}$ & $73.33 \mathrm{a}-\mathrm{e}$ & $55.56 \mathrm{~cd}$ & $45.56 \mathrm{bc}$ & $34.44 \mathrm{cde}$ \\
& Pepper & $97.78 \mathrm{a}$ & $94.44 \mathrm{a}$ & $83.33 \mathrm{abc}$ & $71.11 \mathrm{bc}$ & $57.78 \mathrm{~b}$ & $41.11 \mathrm{bc}$ \\
& Garlic & $93.33 \mathrm{ab}$ & $86.67 \mathrm{abc}$ & $75.56 \mathrm{a}-\mathrm{d}$ & $65.56 \mathrm{bc}$ & $53.33 \mathrm{~b}$ & $43.33 \mathrm{~b}$ \\
& Apron plus & $88.89 \mathrm{ab}$ & $82.22 \mathrm{a}-\mathrm{d}$ & $71.11 \mathrm{~b}-\mathrm{e}$ & $61.11 \mathrm{bc}$ & $47.78 \mathrm{bc}$ & $34.44 \mathrm{cde}$ \\
& Control & $97.52 \mathrm{a}$ & $92.23 \mathrm{ab}$ & $86.67 \mathrm{ab}$ & $77.78 \mathrm{ab}$ & $75.56 \mathrm{a}$ & $55.66 \mathrm{a}$ \\
& Neem & $81.11 \mathrm{bc}$ & $77.78 \mathrm{~b}-\mathrm{e}$ & $66.67 \mathrm{cde}$ & $54.44 \mathrm{~d}$ & $46.67 \mathrm{bc}$ & $32.22 \mathrm{cde}$ \\
& Scent leaf & $82.22 \mathrm{bc}$ & $77.78 \mathrm{~b}-\mathrm{e}$ & $71.11 \mathrm{~b}-\mathrm{e}$ & $60.00 \mathrm{~cd}$ & $44.44 \mathrm{bc}$ & $27.78 \mathrm{cde}$ \\
& Pepper & $74.44 \mathrm{~cd}$ & $67.78 \mathrm{de}$ & $60.00 \mathrm{de}$ & $44.44 \mathrm{~d}$ & $32.33 \mathrm{c}$ & $20.00 \mathrm{e}$ \\
& Garlic & $81.11 \mathrm{bc}$ & $77.78 \mathrm{~b}-\mathrm{e}$ & $66.67 \mathrm{cde}$ & $58.89 \mathrm{~cd}$ & $42.22 \mathrm{bc}$ & $25.56 \mathrm{de}$ \\
& Apron plus & $66.67 \mathrm{~cd}$ & $64.44 \mathrm{e}$ & $56.67 \mathrm{e}$ & $44.44 \mathrm{~d}$ & $34.44 \mathrm{c}$ & $22.22 \mathrm{de}$ \\
& Control & $75.56 \mathrm{~cd}$ & $71.11 \mathrm{bc}$ & $62.22 \mathrm{de}$ & $53.33 \mathrm{~cd}$ & $42.22 \mathrm{bc}$ & $27.78 \mathrm{cde}$ \\
\hline
\end{tabular}

Means followed by the same letters in each column do not differ significantly at $5 \%$ level of probability according to Duncan's Multiple Range Test (DMRT) 
Table 2: Effect of seed treatment and storage duration on seedling vigour of watermelon varieties

\begin{tabular}{|c|c|c|c|c|c|c|c|}
\hline \multirow[b]{2}{*}{ Variety } & \multirow[b]{2}{*}{ Treatment } & \multicolumn{6}{|c|}{ Storage Duration (days) } \\
\hline & & 0 & 30 & 60 & 120 & 150 & 180 \\
\hline \multirow[t]{6}{*}{ Kaolak } & Neem & $17.16 \mathrm{a}$ & $19.30 \mathrm{ab}$ & $16.97 \mathrm{ab}$ & $13.84 \mathrm{a}$ & $12.83 \mathrm{a}$ & $10.74 \mathrm{a}$ \\
\hline & Clove basil & $14.83 \mathrm{abc}$ & $20.62 \mathrm{a}$ & $14.86 a-d$ & $8.43 b c$ & $8.72 b$ & $6.77 b c$ \\
\hline & Pepper & $15.55 \mathrm{abcd}$ & $20.17 \mathrm{ab}$ & $17.54 \mathrm{a}$ & $10.86 \mathrm{ab}$ & $8.83 \mathrm{~b}$ & $6.13 \mathrm{bcd}$ \\
\hline & Garlic & $15.85 \mathrm{a}$ & $16.24 \mathrm{bcd}$ & $12.33 \mathrm{cde}$ & $10.33 \mathrm{abc}$ & $8.11 \mathrm{bc}$ & $6.39 b c$ \\
\hline & Apron plus & $15.19 \mathrm{ab}$ & $17.37 \mathrm{a}-\mathrm{d}$ & $12.80 \mathrm{~b}-\mathrm{e}$ & $8.12 b c$ & $7.14 \mathrm{bc}$ & $4.98 \mathrm{bc}$ \\
\hline & Control & $15.67 \mathrm{a}$ & $19.23 \mathrm{ab}$ & $15.87 \mathrm{abc}$ & $13.61 \mathrm{a}$ & $12.43 \mathrm{a}$ & $9.84 a$ \\
\hline \multirow[t]{6}{*}{ Sugar Baby } & Neem & $11.65 \mathrm{cde}$ & $15.25 \mathrm{cde}$ & $12.16 \mathrm{cde}$ & $10.04 \mathrm{abc}$ & $7.34 \mathrm{bc}$ & $4.92 \mathrm{~b}-\mathrm{e}$ \\
\hline & Clove basil & $11.52 \mathrm{cde}$ & $16.51 \mathrm{bcd}$ & $12.14 \mathrm{cde}$ & $9.73 b c$ & $7.85 \mathrm{bc}$ & $4.92 \mathrm{~b}-\mathrm{e}$ \\
\hline & Pepper & $11.21 \mathrm{de}$ & $13.73 \mathrm{de}$ & $11.08 \mathrm{de}$ & $7.99 b c$ & $5.56 \mathrm{bc}$ & $3.28 \mathrm{e}$ \\
\hline & Garlic & $12.11 \mathrm{~b}-\mathrm{e}$ & $16.24 \mathrm{bcd}$ & $12.33 \mathrm{cde}$ & $10.04 \mathrm{abc}$ & $6.23 \mathrm{bc}$ & $3.87 \mathrm{cde}$ \\
\hline & Apron plus & $9.57 \mathrm{e}$ & $11.94 \mathrm{e}$ & $8.71 \mathrm{e}$ & $6.56 c$ & $5.07 c$ & $3.44 \mathrm{de}$ \\
\hline & Control & $11.39 \mathrm{cde}$ & $13.72 \mathrm{de}$ & $11.65 \mathrm{cde}$ & $8.64 b c$ & $8.20 b c$ & $5.61 c-e$ \\
\hline
\end{tabular}

Means followed by the same letters in each column do not differ significantly at $5 \%$ level of probability according to Duncan's Multiple Range Test (DMRT)

Table 3: Effect of storage container and storage duration on viability (\%) of watermelon varieties

\begin{tabular}{llllllll}
\hline & & \multicolumn{5}{c}{ Storage Duration (days) } \\
\cline { 3 - 7 } Variety & Container & 0 & 30 & 60 & 120 & 150 & 180 \\
\hline Kaolak & Envelope & $98.89 \mathrm{a}$ & $88.89 \mathrm{a}$ & $80.56 \mathrm{a}$ & $71.11 \mathrm{ab}$ & $58.33 \mathrm{ab}$ & $41.11 \mathrm{~b}$ \\
& Glass Bottle & $95.56 \mathrm{a}$ & $90.56 \mathrm{a}$ & $83.89 \mathrm{a}$ & $76.11 \mathrm{a}$ & $66.67 \mathrm{a}$ & $55.56 \mathrm{a}$ \\
& Tin & $94.44 \mathrm{a}$ & $88.89 \mathrm{a}$ & $75.00 \mathrm{ab}$ & $62.78 \mathrm{bc}$ & $51.67 \mathrm{bc}$ & $39.44 \mathrm{~b}$ \\
Sugar Baby & Envelope & $76.67 \mathrm{bc}$ & $74.44 \mathrm{~b}$ & $66.11 \mathrm{bc}$ & $55.56 \mathrm{~cd}$ & $41.67 \mathrm{~cd}$ & $27.22 \mathrm{c}$ \\
& Glass Bottle & $71.11 \mathrm{c}$ & $67.22 \mathrm{~b}$ & $60.00 \mathrm{c}$ & $48.89 \mathrm{~d}$ & $37.22 \mathrm{~d}$ & $24.44 \mathrm{c}$ \\
& Tin & $82.78 \mathrm{~b}$ & $76.67 \mathrm{~b}$ & $65.56 \mathrm{bc}$ & $53.33 \mathrm{~cd}$ & $42.22 \mathrm{~cd}$ & $26.11 \mathrm{c}$ \\
\hline
\end{tabular}

Means followed by the same letters in each column do not differ significantly at $5 \%$ level of probability according to Duncan's Multiple Range Test (DMRT)

(glass bottle $95.56 \%$ and tin $94.44 \%$ ). The same trend was observed at 30 and 60 days of storage. At 120 days of storage, seeds of 'Kaolak' stored in glass bottle gave the highest viability value though similar to that of seeds of the same variety stored in envelope. Also, it was observed that, seeds of 'Kaolak' stored in glass bottle maintained its viability when compared with other containers throughout the storage duration.

In Table 4, the effect of container and storage duration on seedling vigour of two water melon varieties. Treated 'Kaolak' seeds stored in envelope, glass bottle and tin recorded statistically similar higher values compared with 'Sugar Baby' seeds irrespective of the storage container at 0 day of storage. The same trend was observed at 30 days of storage while at 60 days, treated 'Kaolak' seeds stored in glass bottle recorded the highest value. Also, 'Kaolak' seeds in glass bottle maintained higher vigour as storage period increased compared with other treatments.

Data in Table 5 presents the probit parameters of seed longevity data after storage for 180 days in two water melon varieties. The intercept values (estimates of initial probit germination and a measure of seed germination before storage) indicate that there were higher values in neem and pepper in both varieties. Intercept vales were generally higher in 'Kaolak' for all the treatments than for 'Sugar Baby'. The value of slope indicates the speed of deterioration. Differences were exhibited in most cases in the slope values among the varieties, treatments and containers used. The lowest reduction in speed of deterioration (seed longevity) occurred in 'Kaolak' with scent leaf treatment in glass bottle (4.53 days), similar observation was recorded in 'Sugar Baby' with pepper treatment in 
Table 4: Effect of storage container and storage duration on seedling vigour of watermelon varieties

\begin{tabular}{llllllll}
\hline & & \multicolumn{5}{c}{ Storage Duration (days) } \\
\cline { 3 - 7 } Variety & Container & 0 & 30 & 60 & 120 & 150 & 180 \\
\hline Kaolak & Envelope & $16.41 \mathrm{a}$ & $18.76 \mathrm{a}$ & $16.15 \mathrm{ab}$ & $11.04 \mathrm{ab}$ & $11.03 \mathrm{a}$ & $7.64 \mathrm{a}$ \\
& Glass Bottle & $15.71 \mathrm{a}$ & $19.19 \mathrm{a}$ & $16.75 \mathrm{a}$ & $12.25 \mathrm{a}$ & $9.64 \mathrm{ab}$ & $8.35 \mathrm{a}$ \\
& Tin & $14.50 \mathrm{a}$ & $19.35 \mathrm{a}$ & $13.56 \mathrm{bc}$ & $9.31 \mathrm{bc}$ & $8.36 \mathrm{bc}$ & $6.44 \mathrm{ab}$ \\
Sugar Baby & Envelope & $11.59 \mathrm{~b}$ & $15.05 \mathrm{bc}$ & $11.75 \mathrm{c}$ & $9.72 \mathrm{abc}$ & $7.26 \mathrm{bc}$ & $4.79 \mathrm{bc}$ \\
& Glass Bottle & $10.11 \mathrm{~b}$ & $12.88 \mathrm{c}$ & $10.57 \mathrm{c}$ & $8.64 \mathrm{bc}$ & $6.18 \mathrm{c}$ & $4.03 \mathrm{c}$ \\
& Tin & $12.02 \mathrm{~b}$ & $15.77 \mathrm{~b}$ & $11.71 \mathrm{c}$ & $8.13 \mathrm{c}$ & $6.68 \mathrm{c}$ & $4.20 \mathrm{c}$ \\
\hline
\end{tabular}

Means followed by the same letters in each column do not differ significantly at $5 \%$ level of probability according to Duncan's Multiple Range Test (DMRT)

glass bottle (4.53 days) while control in glass bottle deteriorated faster than others (1.07 days).

There was increase in seed longevity extension in the two varieties after seed treatments by estimates of seed half-life $\left(\mathrm{P}_{50}\right)$ and storage life. Higher estimates of seed half-life and storage life after treatments occurred in 'Kaolak' than in 'Sugar Baby'. In 'Kaolak', estimate of seed storage life was the highest in neem in glass bottle (19.24 months) followed by garlic in glass bottle (14.02 months) and control in glass bottle (13.48 months). Apron plus in tin had the lowest storage life value of 7.94 months. All other treatments had storage life of above 8 months. With 'Sugar Baby', storage life estimate was also the highest in neem stored in envelope (11.50 months) followed by garlic in envelope (9.90 months), control in tin (9.72 months) and clove basil in glass bottle (9.50 months). Pepper in glass bottle had the lowest storage life value of 4.38 months while other treatments had storage life of above 5 months.

\section{DISCUSSION}

Seed treatment had been reported to be effective on the improvement of seed germinability and storability (Mandal et al., 2003). In this study, differential responses in seed germination and seedling vigour were observed among the five seed treatments examined suggesting ample opportunity for selection of seed treatment for maintenance of post-storage seed quality in watermelon. This also supports the findings of Adebisi (2012) who reported efficacy of nine seed invigoration treatment in the improvement of okra seed. Significant differences were observed in seed germination and seedling vigour after treatments at each storage time investigated, hence the need to pay close attention to seed treatments regardless of storage container and environments used. 'Kaolak' seeds dressed with neem powder gave better germination and seedling vigour at the end of 180 days storage.
Seeds of 'Kaolak' dressed with neem, clove basil and pepper were higher when compared with that of 'Sugar Baby'. Also, 'Kaolak' seed dressed with neem powder still recorded a value of seed germination above $50 \%$ at the end of 180 days of storage. Also, at the end of the storage (180 days), seed treated with the organic invigoration treatments had maintained greater germination over the inorganic (apron plus). On the mode of action of the crude plant material treatments, various possibilities have been reported earlier (Basu, 1994, Manda et al., 2003). In the present study, crude plant extract materials were selected based on previous study (Adebisi, 2012) for the possible effectiveness in controlling free radicals reactions as antioxidants, antioxidant-synergist and radiation protective agents (Slater, 1972, Brand et al., 1994). Capsaicin which is an important constituent of chilli (Capsicum frutescens) fruit has been reported to be an inhibitor of lipid peroxidation (Manda et al., 2003). Linalool, allicin, and azadirachtin, the most active ingredient in clove basil, garlic and neem leaves might act as inhibitors of lipid peroxidation thereby partly responsible for the longevity maintenance of stored seeds.

The result revealed significant differences among the two varieties for seed germination and seedling vigour index when stored for 180 days. 'Kaolak' had the best seed germination values during and at the end of the storage. This could be due to differences in genetic constitution of the two varieties evaluated. Differential responses in seed germination and vigour among varieties of crop species with and without treatments in storage have been reported. (Daniel et al., 2012; Adebisi et al., 2012, Kehinde et al., 2019).

On the effect of storage time, seeds treated with neem consistently recorded better seed germination at each storage time investigated. Also, storage of clove basil and pepper powder treated seeds maintained greater seedling vigour at each of the storage time examined. Higher deterioration of seed quality irrespective of invigoration treatments have been reported earlier in dif- 
Table 5: Results of probit modelling of seed longevity data in two water melon varieties after crude plant treatment and storage in different containers under ambient conditions

\begin{tabular}{|c|c|c|c|c|c|c|c|}
\hline Variety & Treatment & Container & $\mathrm{K}_{\mathrm{i}}$ & $1 / \sigma$ & $\sigma$ & $\mathrm{P}_{50}$ & $\begin{array}{l}{ }^{* *} \text { Seed Storage } \\
\text { Life (Months) }\end{array}$ \\
\hline \multirow[t]{18}{*}{ Kaolak } & \multirow[t]{3}{*}{ Neem } & Glass Bottle & 6.30 & -0.24 & 4.21 & 9.62 & 19.24 \\
\hline & & Tin & 2.26 & -0.40 & 2.51 & 5.71 & 11.42 \\
\hline & & Envelope & 1.90 & -0.34 & 2.90 & 5.51 & 11.02 \\
\hline & \multirow[t]{3}{*}{ Apron plus } & Glass Bottle & 1.46 & -0.29 & 3.45 & 5.05 & 10.10 \\
\hline & & Tin & 1.22 & -0.31 & 3.24 & 3.97 & 7.94 \\
\hline & & Envelope & 2.22 & -0.42 & 2.37 & 5.26 & 10.52 \\
\hline & \multirow[t]{3}{*}{ Control } & Glass Bottle & 2.28 & -0.93 & 1.07 & 6.74 & 13.48 \\
\hline & & Tin & 3.59 & -0.58 & 1.71 & 6.14 & 12.28 \\
\hline & & Envelope & 2.00 & -0.32 & 3.12 & 6.24 & 12.48 \\
\hline & \multirow[t]{3}{*}{ Garlic } & Glass Bottle & 1.80 & -0.26 & 3.89 & 7.01 & 14.02 \\
\hline & & Tin & 1.60 & -0.36 & 2.73 & 4.39 & 8.78 \\
\hline & & Envelope & 1.90 & -0.37 & 2.68 & 5.09 & 10.18 \\
\hline & \multirow[t]{3}{*}{ Pepper } & Glass Bottle & 1.81 & -0.30 & 3.33 & 6.04 & 12.08 \\
\hline & & Tin & 2.40 & -0.47 & 2.11 & 5.07 & 10.14 \\
\hline & & Envelope & 3.29 & -0.61 & 1.61 & 5.31 & 10.62 \\
\hline & \multirow[t]{3}{*}{ Clove basil } & Glass Bottle & 1.82 & -0.22 & 4.53 & 6.18 & 12.36 \\
\hline & & Tin & 1.91 & -0.42 & 2.37 & 5.22 & 10.44 \\
\hline & & Envelope & 1.48 & -0.30 & 3.34 & 4.39 & 8.78 \\
\hline \multirow[t]{18}{*}{ Sugar Baby } & \multirow[t]{3}{*}{ Neem } & Glass Bottle & 1.60 & -0.36 & 2.80 & 4.49 & 8.98 \\
\hline & & Tin & 0.76 & -0.24 & 4.24 & 3.12 & 6.24 \\
\hline & & Envelope & 1.57 & -0.27 & 3.66 & 5.75 & 11.50 \\
\hline & \multirow[t]{3}{*}{ Apron plus } & Glass Bottle & 0.86 & -0.24 & 4.07 & 3.49 & 6.98 \\
\hline & & Tin & 0.77 & -0.23 & 4.41 & 3.43 & 6.86 \\
\hline & & Envelope & 0.78 & -0.26 & 3.81 & 2.97 & 5.94 \\
\hline & \multirow[t]{3}{*}{ Control } & Glass Bottle & 0.69 & -0.23 & 4.33 & 2.98 & 5.96 \\
\hline & & Tin & 1.51 & -0.31 & 3.21 & 4.86 & 9.72 \\
\hline & & Envelope & 1.02 & -0.24 & 4.07 & 4.17 & 8.34 \\
\hline & \multirow[t]{3}{*}{ Garlic } & Glass Bottle & 0.95 & -0.20 & 3.81 & 3.60 & 7.20 \\
\hline & & Tin & 1.47 & -0.35 & 2.87 & 4.21 & 8.42 \\
\hline & & Envelope & 1.71 & -0.34 & 2.89 & 4.95 & 9.90 \\
\hline & \multirow[t]{3}{*}{ Pepper } & Glass Bottle & 0.48 & -0.22 & 4.53 & 2.19 & 4.38 \\
\hline & & Tin & 1.84 & -0.42 & 2.33 & 4.30 & 8.60 \\
\hline & & Envelope & 1.07 & -0.31 & 3.21 & 3.44 & 6.88 \\
\hline & \multirow[t]{3}{*}{ Clove basil } & Glass Bottle & 1.16 & -0.24 & 4.08 & 4.75 & 9.50 \\
\hline & & Tin & 1.15 & -0.28 & 3.57 & 3.51 & 7.02 \\
\hline & & Envelope & 1.05 & -0.27 & 3.64 & 3.82 & 7.64 \\
\hline
\end{tabular}

$\mathrm{Ki}$ - intercept, $1 / \sigma$ - slope, $\sigma$ - time taken for seed lot to lose 1 probit viability

${ }^{\star} \mathrm{P} 50$ - seed half-life in days

** Seed storage life estimated as P50 value multiplied by 2 then divided by the 30 days of a month 
ferent crop species (Ajala and Adebisi, 2005; Adebisi and Oyekale, 2005). In the present study, gradual decline in seed germination and seedling vigour level was observed irrespective of the pre-storage seed treatment materials with advance in storage times and became pronounced at 180 days (6 months) of storage. Higher seed germination and vigour were maintained at 30 to 150 days of storage. The sharp decline could be due to the deteriorative processes which were enhanced by the higher temperature $\left(30^{\circ} \mathrm{C}\right)$ and relative humidity $(75 \%)$ under tropical humid conditions.

With respect to storage containers, 'Kaolak' seeds stored in glass bottle consistently gave higher germination and seedling vigour values. This finding conforms to expectation as seeds stored in air tight containers maintain seed qualities longer than non-air tight packaging materials like envelopes which absorb moisture from the surrounding atmosphere. This finding agrees with the report of Kumar and Singh (1983) that the seeds of sesame stored in glass bottles maintained satisfactory germination throughout storage period while seeds stored in gunny bags lost viability after six months of storage. Majhi and Bandopadhyay (1993) also reported that freshly harvested groundnut seeds dried to moisture content of $9 \%$ stored in glass bottles for one to nine months had the highest seed viability, root and shoot length and seedling dry mass when compared to seed stored in paper and cloth bag.

On probit modelling, the result showed that the water melon seeds deteriorated at different rate, irrespective of the invigoration material and storage container in which it is been stored for a period of 180 days. 'Kaolak' seeds dressed with neem and stored in glass bottle had the highest estimate of storage life (19.24 months) followed by 'Kaolak' seed treated with garlic in glass bottle (14.02 months) and control in glass bottle (13.48 months) while 'Sugar Baby' treated with pepper in glass bottle had the lowest storage life value of 4.38 months. In other words, the PROBIT modelling predicted that 'Kaolak' seeds can be stored for an average of 19 months if the seeds are put under good storage conditions. Authors like Adebisi et al. (2003, 2008), Esuruoso (2010), Adebisi and Oyekale (2005), Oni (2012) and Kehinde (2018) have also utilized probit modelling to predict storage life of soybean, rice, kenaf, okra, and sesame, respectively under ambient humid storage conditions.

\section{CONCLUSIONS}

Differences were observed in the two seed quality traits examined in water melon due to differences in variety, seed treatment and storage period. 'Kaolak' was the best in storage in terms of seedling vigour and viabil- ity. The use of organic materials especially neem leaf and clove basil leaf powder proved much better for maintaining germinability and seedling vigour and extension of seed longevity than inorganic material.

\subsection{RECOMMENDATION}

The findings from this study showed that maintenance of seed quality in watermelon using crude plant powders is advantageous in the humid tropical conditions. Therefore, since these seed crude plant materials utilized for treating watermelon seeds are cheap, readily available and environmental friendly, these findings will be of benefit to small and medium scale investment involved in seed production in Nigeria, where resources for cold storage are scarce. Therefore, seeds could be stored in glass bottles and preferably with either neem leaf or clove basil leaf powder.

\section{REFERENCES}

Adebisi, M. A. (2012). Efficacy of plant and chemical materials on the quality of okra seed stored under natural ageing conditions. Nigerian Journal of Horticulture, 17, 157-168.

Adebisi, M. A., Daniel, I. O. and Ajala, M. O. (2003). Storage life of soybean seed after seed dressing. Journal of Tropical Agriculture, 42, 3-7.

Adebisi, M.A., Esuruoso, O. A., Adetumbi, J. A., Abdul-Rafiu, A. M., Kehinde, T. O., Ajani, O. O., and Agboola, O. (2013). Shelf life of Kenaf (Hibiscus cannabinus L.) seed stored under humid tropical conditions. Plant Breeding and Seed Science Journal, 67, 75-86. https://doi.org/10.2478/v10129-0110071-5

Adebisi, M. A and Oyekale, K. O. (2005). Effect of seed treatment and storage containers on the maintenance of viability of okra seed. Asset Journal Series, A5(1), 81-89.

Adebisi, M. A., Ola, J. A., Akintobi, D. C. A and Daniel, I. O. (2008). Storage life of sesame (Sesamum indicum L.) seed under humid tropical conditions. Seed Science and Technology, 36, 379-387. https://doi.org/10.15258/sst.2008.36.2.11

Adebisi, M. A., Abdul-Rafiu, A.M., Abdul, R. S., Daniel, I. O. and Tairu, F. M. (2012). Seed longevity and vigour of watermelon (Citrillus lanatus (Thunbg.) Mansf.) seed stored under ambient humid tropical conditions. Nigerian Journal of Horticultural Science, 17, 169-178.

Amadi, E. N., Barimalaa, I. S., Blankson C. D., and Achinewhu, S. C. (2003). Melon (Citrullus vulgaris) seeds as a possible substrate for the production of tempe. Journal of Plant Foods for Human Nutrition, 53, 3-11. https://doi.org/10.1023/ B:QUAL.0000041146.80222.8d

Ajala, M. O. and Adebisi, M. A. (2005). Effect of storage on the viability of treated soybean seed. Nigerian Journal of Ecology, 6, $1-6$.

Basu, R. N. (1994). An appraisal of research on wet and dry 
physiological seed treatments and their applicability with special reference to tropical and sub-tropical countries. Seed Science and Technology, 22, 107-126.

Brand, L. M. Share, K. L, Loomans, M. E. and Reller, H. M. (1994). Anti-inflammatory pharmacology and mechanism of orally active casaicinanalogy. Agent Actions, 31, 329-349. https://doi.org/10.1007/BF01997628

Daniel. I. O., Oyekale, K. O., Ajala, M. O., Sanni, L. O., Okelana, M .A., Adetumbi, J. A., Akintoni, D. C. A. and Adebisi, M. A. (2012). Moisture sorption in commercial hybrid maize (Zea mays L) seeds during storage at ambient tropical conditions. Research Journal of Seed Science, 5(1), 32-37. https://doi.org/10.3923/riss.2012.32.37

Deible, K. E. and Swanson, K. M. J. (2001). Cereal and cereal products, in: Compedium of Methods for the Microbiological Examination of Foods. Downes, f.p. (eds).Academic press, New York. https://doi.org/10.2105/9780875531755ch55

Demir, I. Kenanoglu, B. B., Hay, F., Mavi, K. and Celikkol, T. (2011). Determination of seed moisture contents for the viability equation for watermelon, melon and cucumber seeds. Seed Science and Technology, 39, 527-532. https://doi. org/10.15258/sst.2011.39.2.23

Duncan, D. B. (1955). Multiple Range and Multiple F-tests. Biometrics II, 1-42. https://doi.org/10.2307/3001478

Ellis, R. H and Roberts, E. H. (1980). Improved equation for the prediction of seed longevity. Annuals of Botany, 45, 13-30. https://doi.org/10.1093/oxfordjournals.aob.a085797

Esuruoso, O. A. (2010). Effect of storage duration and seed invigoration treatments on quality of kenaf (Hibiscus cannabinus L.) seed stored under ambient conditions. M. Agric. Dissertation. Department of Plant Breeding and Seed Technology, Federal University of Agricuture Abeokuta, Nigeria. 81pp.

Huxley, A. (1992). The new rhs dictionary of gardening. Macmillan Press. Long island, New York. 5 - 8.

International Seed Testing Association (ISTA). (1995). "Internal rules for seed testing Rules 1995." Seed science and Technology, 13, 322-326.

Jeffrey, C. (2005). Appendix: an outline classification of the $\mathrm{Cu}$ curbitaceae. Biology and
Utilization of the cucurbitaceae. Ithaca, New York, Cornell University. 2005,

Kehinde, T. O. (2018). Potential Longevity of Kenaf (Hibiscus cannabinus L.) seeds under accelerated ageing. Nigerian Journal of Seed Science, 2, 56-68.

Kehinde, T. O., Adebisi, M. A., Omotosho, R. B. Olosunde, O. M. (2019). A study on seedling vigour and storability potential in pigeon pea (Cajanus cajan (L.) Millsp.) Genotypes Nigerian Journal of Seed Science, 3, 77-89.

Kumar, K. And Singh, J., (1983). Effect of fungicidal seed treatment, duration and types of container on viability of sesame during storage. Indian Journal of Mycology and Plant Pathology, 62, 28-34.

Mahesh, B. and R. Hunje. (2008). Effect of seed treatment with botanicals on storability of soybean. Karnataka Journal of Agricultural Science, 21(3), 357-360.

Majhi, A. and Bandopadhyay, P. K., (1993). Vigour and viability of groundnut seed Cv. JL24 under different storage containers Environment and Ecology, 11, 930-932.

Mandal, A. K., De, B. K. and Basu, R. N. (2003). Seed invigoration treatment on different seed sizes of wheat (Triticum aestivum L.) for improved storability and field performance. Seed Science and Technology, 31, 379-388. https:// doi.org/10.15258/sst.2003.31.2.14

Oni, O. D., (2012). Comparative efficacy of crude plant powders on physiological quality of sesame (Sesamum indicum L.) seeds stored under ambient conditions. M. Agric Dissertation, Plant Breeding and Seed Technology Department, Federal University of Agriculture, Abeokuta, Nigeria. Pp 101.

Priestley, D. A., (1986). Seed Aging, Cornell University Press USA. Journal of Experimental Botany, 38(4), 724-725.

SAS Institute Inc. (2002). The SAS System of Windows, Release 9.0, SASI, Cary, NC, USA.

Slater, T. P. (1972). Free radical scavengers, In: Free radical mechanisms in tissue injury. pp. 48- 64. Pion Ltd., London. 